\title{
Response to Optic nerve sheath diameter in critically ill patients: nuances and interpretation
}

\author{
Ziyue Yang, Shuguang Zhang and Tongwen Sun * (D)
}

\section{To the Editor:}

We thank Dr. Lal and his colleagues for their attention to our study in Critical Care. First of all, we are very pleased to see their recommendations and acknowledge that there is still a lot of work to be done to explore the influencing factors of intracranial pressure (ICP)/optic nerve sheath diameter (ONSD). In addition to the serum albumin, serum sodium, and bedside angle mentioned in this study, there are many external factors that affect the ICP/ONSD judgment of sepsis-associated encephalopathy (SAE), including blood glucose, sedative use, albumin use, diuretic use, respiratory alkalosis, inspiration to expiration ratio, steroid use and withdrawal, and blood pressure; vasoactive drug use may affect intracranial blood flow and ICP/ONSD [1-3].

We understand the concern of Lal et al. that basic data such as hypertension and steroid history have an uncertain impact on the basal level of ICP/ONSD. The reason why it is not included in the table is that, on the one hand, most of the patients in the three groups in our study are overlapping (Fig. 1), so the medical history of patients in different groups is similar. On the other hand, the sample size of our initial study was very small, and the frequency of patients taking long-term steroids was very low in our study population.

In addition, with regard to the baseline data of blood pressure when measuring ONSD, since our small observational study measured patients when their vital signs were stable, most patients' blood pressure was in the normal range. However, the concern is that some patients use vasopressor or antihypertensive drugs, and we

\section{* Correspondence: suntongwen@163.com}

General ICU, The First Affiliated Hospital of Zhengzhou University, Henan Key Laboratory of Critical Care Medicine, Zhengzhou Key Laboratory of Sepsis, Zhengzhou 450052, China

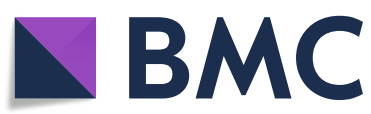

are not sure whether the use of drugs will affect the measurement. Furthermore, we have summarized the blood pressure of the three groups when measuring ONSD in our previous study [4]. There was no statistical difference among the three groups.

Finally, the effects of steroid use and sudden withdrawal on ICP are not clear [5], and steroid deficiency caused by sepsis cannot be accurately quantitatively evaluated. We believe that more studies will be carried out in the future to evaluate the influencing factors of ICP/ ONSD, and more studies should focus on the accuracy of ICP estimation by ONSD.

\section{Acknowledgements \\ None.}

\section{Authors' contributions \\ ZYY and SGZ designed the study. TWS edited the English text of this manuscript. All authors participated in drafting and reviewing the manuscript. All authors read and approved the final version of the manuscript.}

\section{Funding}

This study was supported by the Scientific and Technological Innovation Leaders in Central Plains (Grant No. 194200510017), the Provincial Ministry Co-Construction Project from the Medical Scientific and Technological Research Program of Henan Province (Grant No. SBGJ2018020), the "51282" Project Leaders of Scientific and Technological Innovative Talents from Health and Family Planning Commission in Henan Province (2016-32), and the Science and Technology People-Benefit Project of Zheng Zhou (2019KJHM0001).

\section{Availability of data and materials}

All data generated or analyzed during this study are included in this published article and its supplementary information files.

\section{Ethics approval and consent to participate}

This study has been approved by the Scientific Research and Clinical Trial Ethics Committee of the First Affiliated Hospital of Zhengzhou University (Code 2020-KY-035).

(0 The Author(s). 2020 Open Access This article is licensed under a Creative Commons Attribution 4.0 International License, which permits use, sharing, adaptation, distribution and reproduction in any medium or format, as long as you give appropriate credit to the original author(s) and the source, provide a link to the Creative Commons licence, and indicate if changes were made. The images or other third party material in this article are included in the article's Creative Commons licence, unless indicated otherwise in a credit line to the material. If material is not included in the article's Creative Commons licence and your intended use is not permitted by statutory regulation or exceeds the permitted use, you will need to obtain permission directly from the copyright holder. To view a copy of this licence, visit http://creativecommons.org/licenses/by/4.0/ The Creative Commons Public Domain Dedication waiver (http://creativecommons.org/publicdomain/zero/1.0/) applies to the data made available in this article, unless otherwise stated in a credit line to the data. 


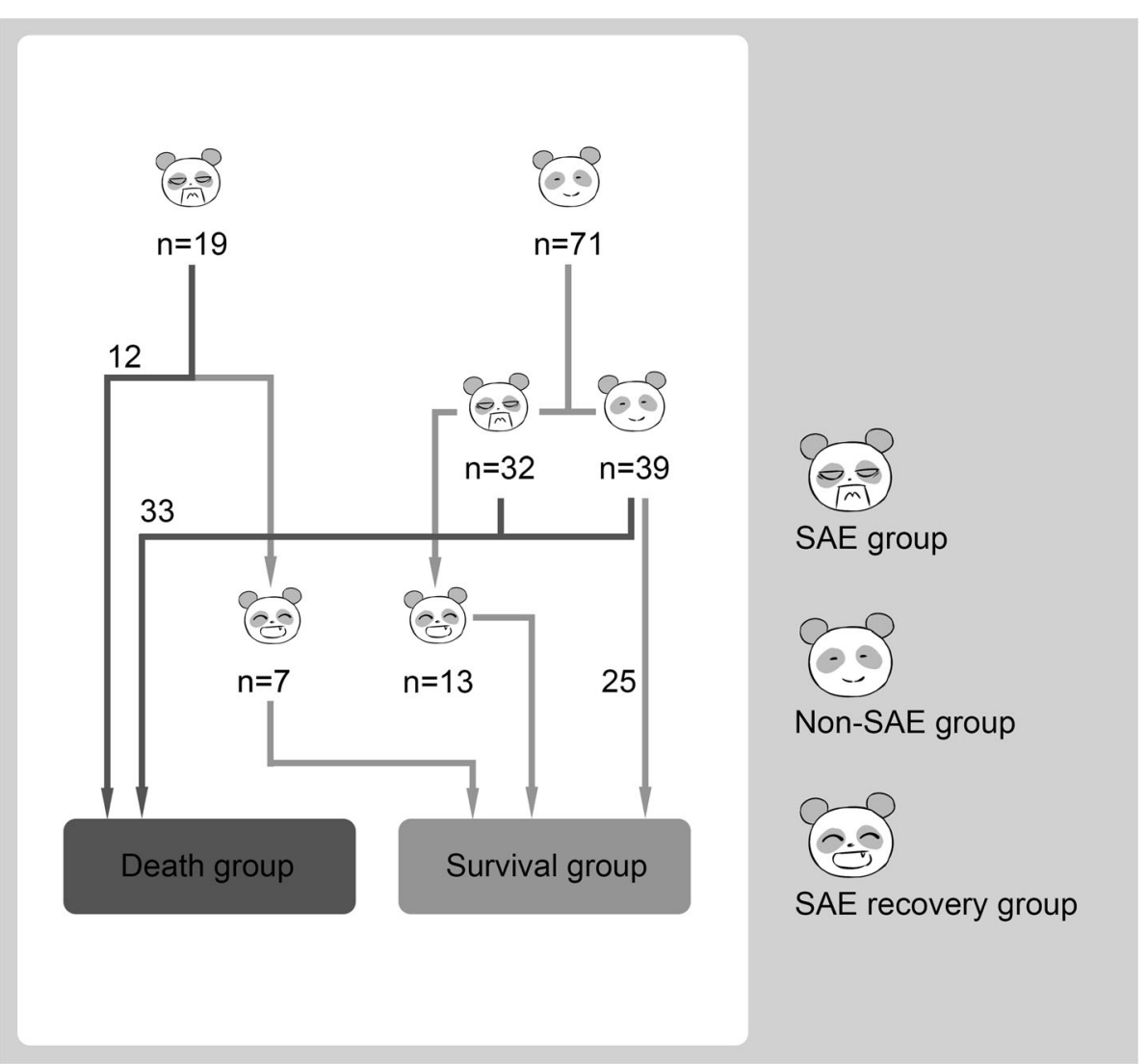

Fig. 1 The flow chart of this study

\section{Consent for publication}

Not applicable.

\section{Competing interests}

The authors declare that they have no competing interests.

Received: 5 June 2020 Accepted: 3 July 2020

Published online: 14 July 2020

\section{References}

1. Donnelly J, Budohoski KP, Smielewski P, Czosnyka M. Regulation of the cerebral circulation: bedside assessment and clinical implications. Critical care (London, England). 2016;20(1):129.

2. Brandi G, Stocchetti N, Pagnamenta A, Stretti F, Steiger P, Klinzing S. Cerebral metabolism is not affected by moderate hyperventilation in patients with traumatic brain injury. Critical care (London, England). 2019; 23(1):45.

3. Koziarz A, Sne N, Kegel F, Nath S, Badhiwala JH, Nassiri F, Mansouri A, Yang K, Zhou Q, Rice T, et al. Bedside optic nerve ultrasonography for diagnosing increased intracranial pressure: a systematic review and meta-analysis. Ann Intern Med. 2019:171(12):896-905.

4. Yang Z, Qin C, Zhang S, Liu S, Sun T. Bedside ultrasound measurement of optic nerve sheath diameter in patients with sepsis: a prospective observational study. Critical Care. 2020;24(1).

5. Gudeman SK, Miller JD, Becker DP. Failure of high-dose steroid therapy to influence intracranial pressure in patients with severe head injury. J Neurosurg. 1979;51(3):301-6.

\section{Publisher's Note}

Springer Nature remains neutral with regard to jurisdictional claims in published maps and institutional affiliations. 